\title{
Anesthetic recovery and hemodynamic effects of continuous thiopental infusion versus halothane for maintenance anesthesia in patients undergoing ocular surgery ${ }^{1}$
}

\author{
Recuperação anestésica e efeitos hemodinâmicos da infusão contínua de tiopental versus \\ halotano na manutenção da anestesia em pacientes submetidos à cirurgia ocular.
}

\author{
Mehrdad Shoroghi', Farshid Farahbakhsh"I, Mehrdad Sheikhvatan ${ }^{\mathrm{III}}$, Mahmood Sheikhfathollahi' ${ }^{\mathrm{IV}}$, Ali Abbasi ${ }^{\mathrm{V}}$, Azam Talebi ${ }^{\mathrm{VI}}$ \\ ${ }^{1}$ Research performed at Department of Anaesthesia, Farabi Eye Hospital, Tehran University of Medical Sciences, Tehran, Iran.

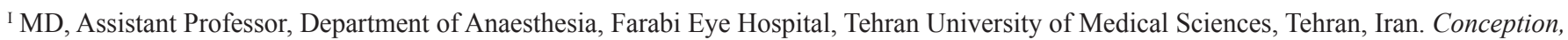 \\ design, .data acquisition, drafting and revising the article. Responsible for anaesthesia procedure and for the integrity of the work as a whole.

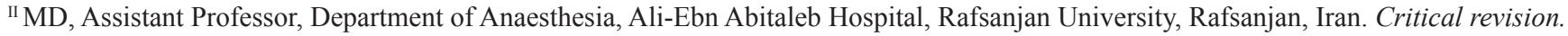

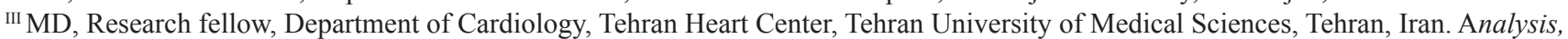 \\ interpretation of data, drafting and revising the article. \\ ${ }^{\mathrm{IV}} \mathrm{PhD}$, Research fellow, Department of Cardiology, Tehran Heart Center, Tehran University of Medical Sciences, Tehran, Iran. Critical revision, \\ analysis and interpretation of data. \\ ${ }^{\mathrm{V}} \mathrm{MD}, \mathrm{PhD}$ fellow, Department of Epidemiology, University Medical Center Groningen, Groningen, the Netherlands. Analysis and interpretation of \\ data, drafting the article and critical revision. \\ ${ }^{\mathrm{vI}}$ Bachelor of Science, Nurse, Department of Anaesthesia, Farabi Eye Hospital, Tehran University of Medical Sciences, Tehran, Iran. Helped with \\ anaesthesia technical procedures and collection of information.
}

\begin{abstract}
Purpose: To investigate anesthesia recovery and hemodynamic status in patients under thiopental infusion or halothane maintenance anesthesia undergoing ocular surgery. Methods: Fifty-nine voluntary patients undergoing ocular surgery in Farabi hospital were allocated to one of two maintenance anesthesia groups: inhaled halothane, 0.8 to 1 per cent, (group I, n=37) and thiopental infusion, 10 to $12 \mathrm{mg} / \mathrm{kg}$ /hour, (group II, $\mathrm{n}=22$ ). Hemodynamic parameters were recorded at the time of patient entrance to the operation room and at the $1,2,5,10,15,20,25,30,35$, and 40 minutes following anesthesia. Anesthesia recovery variables were also compared between the two groups. Results: In group I, arterial blood pressure at 10 to $40 \mathrm{~min}$ and heart rate at 1 and 25 min after the administration of anesthetics were significantly lower when compared with group II $\left(\mathrm{W}^{2}=25.10, \mathrm{p}=0.005\right)$. Arterial oxygen saturation was similar in the two groups over the whole points of time. The time intervals between the end of surgery and beginning of the first body movements and respiratory efforts were significantly longer in group received halothane $(p<0.001)$. Conclusions: Continuous infusion of thiopental can be applied effectively and safely for maintenance of anesthesia. In comparison with halothane, it is associated with lower changes of intraoperative hemodynamics and faster anesthesia recovery.
\end{abstract}

Key words: Thiopental. Halothane. Anesthesia Recovery Period. Hemodynamic. Eye. Surgery.

\section{RESUMO}

Objetivo: Investigar a recuperação anestésica e as condições hemodinâmicas em pacientes submetidos a infusão de tiopental ou hatotano na manutenção da anestesia na cirurgia ocular. Métodos: Cinquenta e nove voluntários submetidos a cirurgia ocular no Hospital Farabi foram distribuídos em dois grupos de manutenção anestésica: Grupo I (n=37) inalação halotano, 0,8 a 1\% e Grupo II (n=22) infusão de tiopental, 10 a $12 \mathrm{mg} / \mathrm{kg} /$ hora. Foram registrados parâmetros hemodinâmicos da entrada dos pacientes na sala operatória até 1, 2, 5, $10,15,20,25,30,35$ e 40 minutos durante a anestesia. Variáveis de recuperação anestésica foram também comparados entre ambos os grupos. Resultados: No Grupo I a pressão arterial nos 10 a 40 minutos e avaliação cardíaca em um e 25 minutos após a administração dos anestésicos foram significantes mais baixos comparados com o Grupo II ( $\left.\mathrm{W}^{2}=25.10, \mathrm{p}=0.005\right)$. A saturação de oxigênio foi similar nos dois grupos durante todos procedimentos. Os intervalos de tempo entre o final da cirurgia e início dos primeiros movimentos e a respiração foram significativamente mais prolongados no grupo que recebeu halotoano $(\mathrm{p}<0.001)$. Conclusões: A infusão continua de tiopental pode ser aplicado efetivamente e com segurança na manutenção da anestesia. Em comparação com halotano as mudanças hemodinâmicas foram menores e a recuperação anestésica mais rápida.

Descritores: Tiopental. Halotano. Período de Recuperação da Anestesia. Hemodinâmica. Olho. Cirurgia. 


\section{Introduction}

Selection of the best anesthetic protocol with minimized complications is quite challenging and much scientific efforts have been focused on qualifying anesthesia. The use of volatile and induction agents can lead to hemodynamic alterations and serious cardiovascular and respiratory complications that have been documented in several animal models ${ }^{1}$. These side effects have been more marked with some agents such as halothane and thiopental. In some studies, it has been shown that the halothane could induce a profound alteration in heart and respiratory rates and abnormal cardiac rhythms included ventricular fibrillation, ventricular bigeminy, and multifocal ventricular rhythms were occurred by the use of this inhalational agent ${ }^{1-4}$. Furthermore, the changes in both systemic and cerebral hemodynamics have been shown in the patients undergoing general anesthesia by using thiopental ${ }^{5-7}$.

Although a relatively high incidence of cardiac arrhythmias and hemodynamic alterations during halothane and thiopental anesthesia has been reported in animal models, these changes have not been clearly investigated in humans. Moreover, since these two agents are used extensively in general anesthesia of patients undergoing various types of surgeries, it appears that a more detailed investigation in surgical patients is needed. There are a few reports to examine the continuous intravenous (IV) infusion of thiopental for maintenance anesthesia. The purpose of the present study was to compare the anesthesia recovery and hemodynamic status in patients under IV infusion thiopental versus halothane maintenance anesthesia undergoing ocular surgery.

\section{Methods}

In a prospective clinical trial study, 59 voluntary patients of ASA grade 1 and 2 aged 22-86 years old with ocular and candidate for surgery in Farabi Hospital, Tehran, Iran were included. The investigation was approved by the Educational Hospital Ethics Committee, governing the participation of human subjects in research at the Tehran University of Medical Sciences, according to the principles outlined in the Declaration of Helsinki. The procedure and type of anesthetics were explained to the patients, and written informed consents were obtained from all the patients before induction of anesthesia. The participants with the history of cardiovascular disease, allergy to barbiturates, acute alternative porphyria, respiratory disorders, persistent asthma, Addison's disease, liver diseases, renal failure, myxedema, severe anemia, or myasthenia gravis were excluded. All patients were given an intravenous injection of fentanyl $(1.5 \mu \mathrm{g} / \mathrm{kg})$, diazepam $(0.1 \mathrm{mg} / \mathrm{kg}), 5$ minutes before anesthesia induction. All patients underwent induction of anesthesia with a single bolus IV thiopental (4 to $6 \mathrm{mg} / \mathrm{kg}$ ) and oxygen. After evaluating the effect of premedication, patients were randomly allocated to receive maintenance anesthesia by using either inhaled halothane (group $\mathrm{I}, \mathrm{n}=37$ ) after the tracheal intubation or continuous infusion of thiopental (group II, $\mathrm{n}=22$ ) immediately after the anesthesia induction. Endotracheal intubation was facilitated with atracurium (0.5-0.7 $\mathrm{mg} / \mathrm{kg} \mathrm{IV}$, maximum dose of $2.5 \mathrm{mg})$ and the mechanical ventilation was set at a rate of 12 per min and a volume of 10 $\mathrm{ml} / \mathrm{kg}$. Upon completion of surgery, the neuromuscular block was antagonized with neostigmine $(80 \mu \mathrm{g} / \mathrm{kg}$, maximum dose of 2.5 $\mathrm{mg}$ ) and atropine $(40 \mu \mathrm{g} / \mathrm{kg})$.

In group I, inhaled concentration of halothane was set at $0.8 \%$ to $1 \%$. The group II was given thiopental infusion of 10 to $12 \mathrm{mg} / \mathrm{kg} /$ hour by using infusion pump. This infusion rate was maintained at a fix value during operation. Halothane was intraoperatively inspired with similar concentration. The doses of the halothane inhalation and thiopental infusion were chosen based on the clinical experience of the anesthetist of the Ophthalmology Surgery Hospital.

Hemodynamic parameters including systolic blood pressure, heart rate, and arterial oxygen saturation, were recorded at the time of patient entrance to the operation room and at the $1,2,5,10,15,20,25,30,35$, and 40 minutes after the induction of anesthesia. Anesthesia recovery parameters were compared between the two groups. For this assessment, the time intervals between the end of surgery and the beginning of the first body movements, the first respiratory efforts, extubation, and patients' transferring to recovery room were recorded and examined. The depth of anesthesia was objectively and subjectively evaluated during the anesthesia and recovery period, respectively. The patients' movement and hemodynamics were considered for the objective assessment of the anesthesia. In the recovery room, all the patients were asked about the any sensation and sound during the general anesthesia.

We calculated a sample size so that a between-group mean difference in recovery time would permit a two-tailed Type I error rate of $\alpha=0.05$ with a power of $69 \%$. This analysis indicated that a sample size of at least 20 patients per group was necessary. After randomization of the patients who fulfilled the inclusion criteria, 59 patients who had the complete records for the intraoperative parameters and anesthesia recovery were selected.

Numerical variables were presented as mean $\pm \mathrm{SD}$, while categorized variables were summarized by percentages. 
Continuous variables were compared using the Student's t test or nonparametric Mann-Whitney U test whenever the data did not appear to have normal distributions, and categorical variables were compared using chi-square or Fisher's exact test, as required. Modeling the mean response over time was the main feature of analysis we followed to deal with the longitudinal data. In other words, since all individuals were measured at the same set of occasions, we performed separate Analyzing Response Profiles ${ }^{8}$ using Proc Mixed in SAS to compare blood pressure, heart rate, and arterial oxygen saturation across the two groups. Halothane group and the time of patients' entrance to the operation room were considered as the reference points. Model parameters were estimated using Generalized Least Squares (GLS) estimator. Since Maximum Likelihood (ML) estimate of covariance matrix has well-known bias in finite samples, parameters of covariance matrix were estimated using Restricted Maximum Likelihood (REML) estimation. The type of covariance matrix was specified as unstructured, since we had no prior knowledge concerning the main feature of correlation type among responses across the time. For univariate analysis, the statistical software SPSS version 13.0 for windows (SPSS Inc., Chicago, IL) and for analyzing response profiles, the statistical package SAS version 9.1 for windows (SAS Institute Inc., Cary, NC, USA) were used. All p values were 2-tailed, with statistical significance defined by $\mathrm{p} \leq 0.05$.

\section{Results}

Demographic characteristics and medical history of the patients who received thiopental and halothane are shown in Table 1.

TABLE 1 - Demographic characteristics and medical data of the patients received thiopental and halothane.

\begin{tabular}{lccc}
\hline & $\begin{array}{c}\text { Thiopental group } \\
(\boldsymbol{n}=\mathbf{2 2})\end{array}$ & $\begin{array}{c}\text { Halothane group } \\
(\boldsymbol{n}=37)\end{array}$ & P-value \\
\hline Baseline characteristics: & & & \\
Male gender & 43.2 & 31.8 & 0.384 \\
Age (year) & $65.5 \pm 12.7$ & $65.5 \pm 12.8$ & 0.980 \\
Weight (kg) & $65.4 \pm 12.8$ & $66.6 \pm 12.3$ & 0.726 \\
Hypertension & 32.4 & 13.6 & 0.109 \\
Diabetes mellitus & 13.5 & 0.0 & 0.146 \\
Substance abuse & 5.4 & 0.0 & 0.524 \\
\hline
\end{tabular}

Data are presented as mean $\pm \mathrm{SD}$ (for continuous variables) or percentages (for categorical variables)

$\mathrm{p} \leq 0.05$ from two-sided tests was considered statistically significant
Preoperative patient variables did not differ significantly with respect to gender, age, weight, and the previous histories of hypertension and diabetes mellitus. The depth of anesthesia was similar between groups. Also, the frequencies of current cigarette smoking and opium addiction were similar in the two groups.

In terms of hemodynamic parameters, there were no significant differences in the mean of systolic blood pressure at the time of patients' entrance to the operation room and in time points of one minute and five minutes after the administration of anesthetics; however, blood pressures were significantly appeared lower in halothane group across the other points if time (Table 2).

TABLE 2 - Comparison of blood pressure between the patients received thiopental and halothane.

\begin{tabular}{cccc}
\hline & \multicolumn{3}{c}{ Systolic blood pressure } \\
\cline { 2 - 4 } Time after & $\begin{array}{c}\text { Thiopental } \\
\text { group } \\
\text { anesthesia }\end{array}$ & $\begin{array}{c}\text { Halothane } \\
\text { group } \\
\text { (n=37) }\end{array}$ & P value \\
Minute 0 & $154.1 \pm 34.5$ & $146.4 \pm 33.2$ & 0.405 \\
Minute 1 & $126.2 \pm 47.2$ & $105.0 \pm 28.9$ & 0.062 \\
Minute 2 & $112.8 \pm 38.1$ & $93.0 \pm 27.0$ & 0.036 \\
Minute 5 & $102.4 \pm 31.1$ & $89.8 \pm 27.0$ & 0.118 \\
Minute 10 & $110.3 \pm 27.3$ & $94.1 \pm 26.8$ & 0.031 \\
Minute 15 & $118.0 \pm 32.2$ & $93.9 \pm 24.7$ & 0.004 \\
Minute 20 & $125.0 \pm 32.6$ & $97.7 \pm 24.5$ & 0.001 \\
Minute 25 & $123.5 \pm 28.4$ & $100.9 \pm 15.1$ & $<0.001$ \\
Minute 30 & $132.0 \pm 30.9$ & $108.2 \pm 17.4$ & $<0.001$ \\
Minute 35 & $129.3 \pm 17.9$ & $110.9 \pm 18.9$ & $<0.001$ \\
Minute 40 & $133.5 \pm 15.9$ & $125.9 \pm 8.5$ & 0.043 \\
\hline
\end{tabular}

Data are presented as mean $\pm \mathrm{SD}$

$\mathrm{p} \leq 0.05$ from two-sided tests was considered statistically significant

Also, two studied groups had similar mean heart rate at the time of patients' entrance to the operation room, but heart rates were significantly lower in halothane group over the time points of one minute through twenty five minutes after the administration of anesthetics (Table 3). 
TABLE 3 - Comparison of heart rate between the patients received thiopental and halothane.

\begin{tabular}{cccc}
\hline Time after & \multicolumn{3}{c}{ Heart rate } \\
\cline { 2 - 4 } anesthesia & $\begin{array}{c}\text { Thiopental } \\
\text { group } \\
(\mathbf{n = 2 2})\end{array}$ & $\begin{array}{c}\text { Halothane } \\
\text { group } \\
(\mathbf{n}=\mathbf{3 7})\end{array}$ & P value \\
Minute 0 & $78.2 \pm 16.6$ & $70.9 \pm 11.5$ & 0.074 \\
Minute 1 & $86.8 \pm 22.5$ & $71.3 \pm 16.4$ & 0.007 \\
Minute 2 & $82.5 \pm 21.3$ & $69.9 \pm 16.4$ & 0.020 \\
Minute 5 & $79.1 \pm 17.7$ & $64.7 \pm 15.3$ & 0.002 \\
Minute 10 & $75.2 \pm 15.3$ & $62.6 \pm 10.7$ & 0.001 \\
Minute 15 & $73.1 \pm 12.5$ & $64.9 \pm 14.9$ & 0.026 \\
Minute 20 & $71.2 \pm 12.3$ & $63.3 \pm 13.0$ & 0.023 \\
Minute 25 & $70.4 \pm 12.0$ & $64.0 \pm 8.2$ & 0.032 \\
Minute 30 & $69.6 \pm 12.5$ & $65.7 \pm 7.8$ & 0.150 \\
Minute 35 & $67.2 \pm 11.2$ & $63.0 \pm 5.2$ & 0.107 \\
Minute 40 & $65.9 \pm 9.8$ & $65.6 \pm 4.6$ & 0.919 \\
\hline
\end{tabular}

Data are presented as mean $\pm \mathrm{SD}$

$\mathrm{p} \leq 0.05$ from two-sided tests was considered statistically significant

Arterial oxygen saturation was followed a similar pattern in the two groups across the whole time points (Table 4).

TABLE 4 - Comparison of arterial oxygen saturation between the patients received thiopental and halothane.

\begin{tabular}{cccc}
\hline & \multicolumn{3}{c}{ Arterial oxygen saturation } \\
\cline { 2 - 4 } Time after & $\begin{array}{c}\text { Thiopental } \\
\text { group } \\
\text { (n=22) }\end{array}$ & $\begin{array}{c}\text { Halothane } \\
\text { group } \\
\text { (n=37) }\end{array}$ & P-value \\
Minute 0 & $95.8 \pm 2.7$ & $95.6 \pm 3.4$ & 0.768 \\
Minute 1 & $98.6 \pm 1.1$ & $98.0 \pm 1.9$ & 0.170 \\
Minute 2 & $98.4 \pm 1.0$ & $97.9 \pm 2.1$ & 0.194 \\
Minute 5 & $98.5 \pm 0.9$ & $98.3 \pm 1.2$ & 0.342 \\
Minute 10 & $98.4 \pm 1.0$ & $98.4 \pm 1.1$ & 0.931 \\
Minute 15 & $98.6 \pm 0.9$ & $98.5 \pm 0.9$ & 0.754 \\
Minute 20 & $98.7 \pm 0.9$ & $98.5 \pm 1.0$ & 0.274 \\
Minute 25 & $98.8 \pm 0.9$ & $98.6 \pm 0.9$ & 0.362 \\
Minute 30 & $98.8 \pm 0.9$ & $98.8 \pm 0.8$ & 0.866 \\
Minute 35 & $99.0 \pm 0.7$ & $98.9 \pm 0.6$ & 0.731 \\
Minute 40 & $98.1 \pm 6.5$ & $98.9 \pm 0.6$ & 0.540 \\
\hline
\end{tabular}

Data are presented as mean $\pm \mathrm{SD}$

$\mathrm{p} \leq 0.05$ from two-sided tests was considered statistically significant

Postoperative outcomes of the patients in the two studied groups are shown in Table 5.
TABLE 5 - Postoperative outcome of the patients received thiopental and halothane.

\begin{tabular}{cccc}
\hline Item & $\begin{array}{c}\text { Thiopental } \\
\text { group } \\
(\boldsymbol{n = 2 2 )}\end{array}$ & $\begin{array}{c}\text { Halothane } \\
\text { group } \\
(\boldsymbol{n}=37)\end{array}$ & P value \\
\hline $\begin{array}{c}\text { Time interval between the end of } \\
\text { surgery and beginning of the first } \\
\text { body movements (min) }\end{array}$ & $2.09 \pm 1.18$ & $5.55 \pm 2.48$ & $<0.001$ \\
$\begin{array}{c}\text { Time interval between the end of } \\
\text { surgery and beginning of the first } \\
\text { respiratory efforts (min) }\end{array}$ & $5.24 \pm 2.52$ & $8.96 \pm 3.51$ & $<0.001$ \\
$\begin{array}{c}\text { Time interval between the end of } \\
\text { surgery and extubation (min) }\end{array}$ & $5.04 \pm 2.49$ & $10.52 \pm 4.28$ & $<0.001$ \\
$\begin{array}{c}\text { Time interval between the end } \\
\text { of surgery and transferring to } \\
\text { recovery (min) }\end{array}$ & $6.04 \pm 2.58$ & $17.09 \pm 11.16$ & $<0.001$ \\
$\quad$ Arrhythmia (\%) & 5.4 & & \\
\hline
\end{tabular}

Data are presented as mean $\pm \mathrm{SD}$ (for continuous variables) or percentages (for categorical variable)

$\mathrm{p} \leq 0.05$ from two-sided tests was considered statistically significant

The time intervals between the end of surgery and beginning of the first body movements, the first respiratory efforts, extubation, and transferring to recovery were all longer in group received halothane than in thiopental group.

Wald tests of fixed effects based on an analysis of response profiles of the blood pressure, heart rate, and arterial oxygen saturation levels comparing the thiopental and halothane groups, showed that the patterns of change (interaction between drug and time $)$ in blood pressure $\left(\mathrm{W}^{2}=14.39, \mathrm{p}=0.156\right)$ and in oxygen saturation $\left(\mathrm{W}^{2}=9.23, \mathrm{p}=0.511\right)$ from baseline were not statistically different between the groups, whereas the pattern of change in heart rate from baseline was not the same between groups $\left(\mathrm{W}^{2}=25.10, \mathrm{p}=0.005\right)$ (Figures 1 to 3$)$.

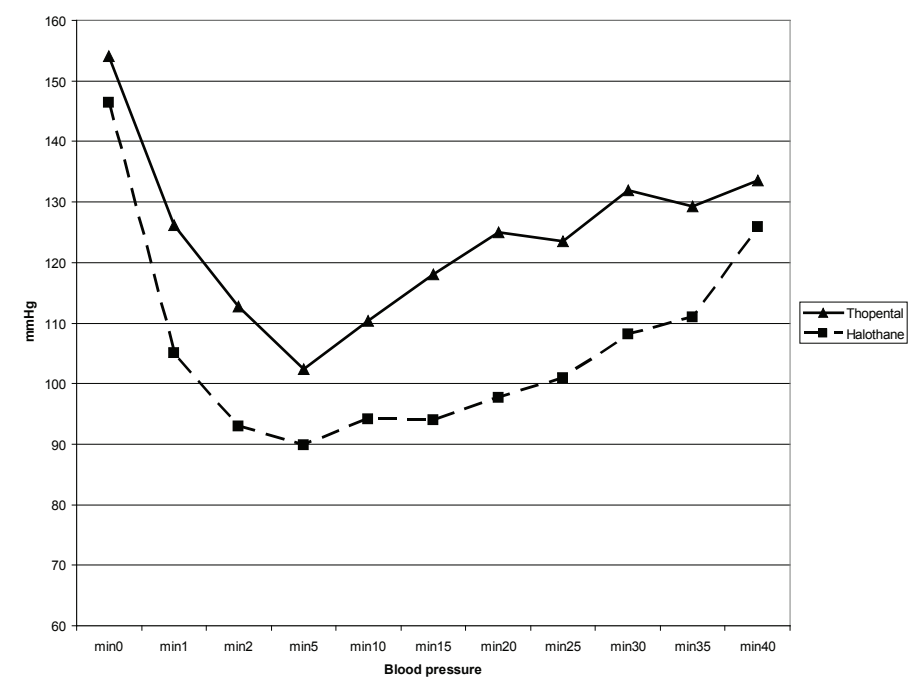

FIGURE 1 - Blood pressure after the administration of thiopental and halothane. 


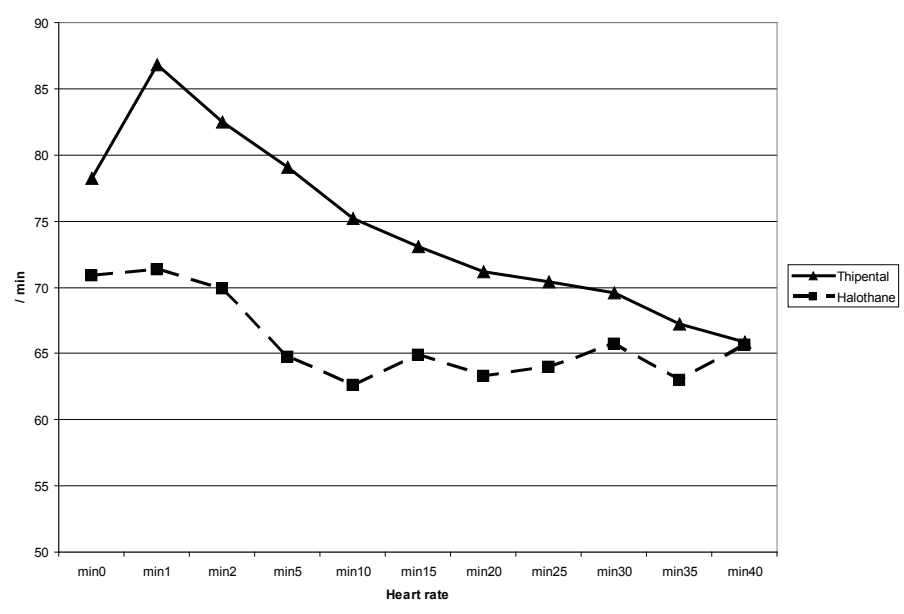

FIGURE 2 - Heart rate after the administration of thiopental and halothane.

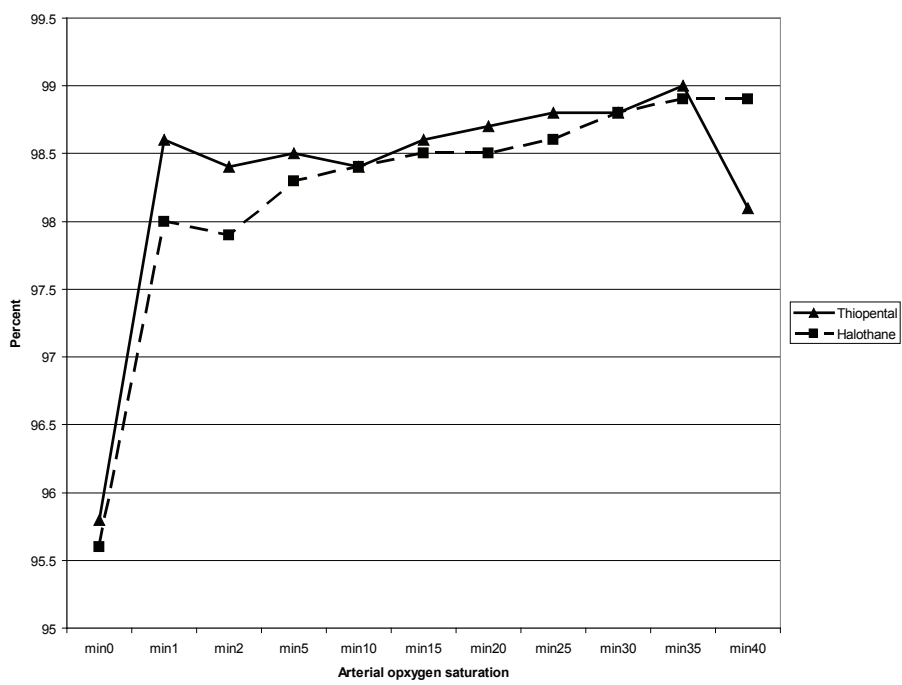

FIGURE 3 - Arterial $\mathrm{O}_{2}$ saturation after the administration of thiopental and halothane.

Estimated regression coefficients and standard errors based on an analysis of response profiles comparing heart rate levels between the two groups revealed that the thiopental group had an additional increase in mean heart rate levels from the time of patients' entrance to the operation room to the time points of 20 minutes, when compared to halothane group. In contrast, the first group had an additional decrease in mean heart rate levels from 20 minutes through the last time point, in comparison with halothane group (Table 6).
TABLE 6 - Estimated regression coefficients and standard errors based on an analysis of response profiles of the heart rate levels comparison between thiopental and halothane groups.

\begin{tabular}{|c|c|c|c|c|c|c|}
\hline Pvalue & $T$ value & $\begin{array}{c}\text { Standard } \\
\text { Error }\end{array}$ & Estimate & Time & Group & Variable \\
\hline$<0.0001$ & 22.24 & 3.1857 & 70.8636 & & & Intercept \\
\hline 0.0739 & 1.82 & 4.0228 & 7.3256 & & Thiopental & Group \\
\hline . & . & . & 0 & & Halothane & Group \\
\hline . & . & . & 0 & 0 & & Minute \\
\hline 0.9081 & 0.12 & 3.9181 & 0.4545 & 1 & & Minute \\
\hline 0.7678 & -0.30 & 3.3708 & -1.0000 & 2 & & Minute \\
\hline 0.0524 & -1.98 & 3.0974 & -6.1364 & 5 & & Minute \\
\hline 0.0070 & -2.80 & 2.9421 & -8.2273 & 10 & & Minute \\
\hline 0.0537 & -1.97 & 3.0456 & -6.0000 & 15 & & Minute \\
\hline 0.0117 & -2.61 & 2.9124 & -7.5909 & 20 & & Minute \\
\hline 0.0253 & -2.30 & 2.9874 & -6.8636 & 25 & & Minute \\
\hline 0.1127 & -1.61 & 3.1883 & -5.1364 & 30 & & Minute \\
\hline 0.0147 & -2.52 & 3.1254 & -7.8636 & 35 & & Minute \\
\hline 0.0808 & -1.78 & 2.9409 & -5.2273 & 40 & Thiopental & Minute \\
\hline . & . & . & 0 & 0 & Thiopental & Group $\times$ Time \\
\hline 0.1054 & 1.65 & 4.9476 & 8.1400 & 1 & Thiopental & Group $\times$ Time \\
\hline 0.2161 & 1.25 & 4.2565 & 5.3243 & 2 & Thiopental & Group $\times$ Time \\
\hline 0.0755 & 1.81 & 3.9113 & 7.0823 & 5 & Thiopental & Group $\times$ Time \\
\hline 0.1670 & 1.40 & 3.7152 & 5.2002 & 10 & Thiopental & Group $\times$ Time \\
\hline 0.8066 & 0.25 & 3.8459 & 0.9459 & 15 & Thiopental & Group $\times$ Time \\
\hline 0.8787 & 0.15 & 3.6777 & 0.5639 & 20 & Thiopental & Group $\times$ Time \\
\hline 0.7972 & -0.26 & 3.7724 & -0.9742 & 25 & Thiopental & Group $\times$ Time \\
\hline 0.3940 & -0.86 & 4.0261 & -3.4582 & 30 & Thiopental & Group $\times$ Time \\
\hline 0.4262 & -0.80 & 3.9467 & -3.1634 & 35 & Thiopental & Group $\times$ Time \\
\hline 0.0610 & -1.91 & 3.7173 & -7.0971 & 40 & Thiopental & Group $\times$ Time \\
\hline
\end{tabular}

$\mathrm{p} \leq 0.05$ from two-sided tests was considered statistically significant

\section{Discussion}

Various types of anesthetic agents may influence and alter hemodynamic status, but these effects are different due to the type of these agents. In the present clinical trial study, we tried to examine the impact of continuous infusion of thiopental and inhaled halothane as maintenance anesthesia on operative hemodynamic status and also compare the time intervals between the end of surgery and the beginning of physical active responses for assessment of the recovery time. According to the obtained results, although systolic blood pressure and heart rate in patients who received thiopental was similar to those received halothane in baseline, these indices, in subsequent time points, were frequently lower in halothane group. Furthermore, postoperative movement, respiratory efforts, and transferring to recovery, following surgery, were initiated faster due to thiopental use compared to halothane. More effect of halothane on hemodynamic status in comparison with other anesthetic agents has been shown in the previous studies. Büch et al. ${ }^{9}$ confirmed more decline of regional blood flow in many tissues induced by halothane. In a study by Goelz 
et al. ${ }^{1}$ it was indicated that both halothane and isoflurane altered heart rate and blood pressure; however, halothane induced a more profound alteration in heart rate and respiratory rate. In addition, in another study by Dedhia et al. ${ }^{2}$ there was a notable reduction in the mean heart rate and systolic blood pressure in group received halothane at 30 seconds followed by a gradual fall. It has been shown that the halothane has a potential role on the conducting tissues of the ventricle and even its increased sensitivity to catecholamine blood pressure alterations and arrhythmias resulted primarily from its action on these tissues ${ }^{10}$. Moreover, it has been confirmed that halothane caused a significant and dose-dependent decrease in cardiac output and this reduction was dependent to halothane effects on antipyrine disposition profoundly affected by this anesthetic agent ${ }^{11}$.

Besides, alteration in hemodynamic status has been also caused by the use of thiopental and this effect can be mainly related to the change of cardiac parasympathetic tone ${ }^{12}$. However, the supportive roles of thiopental have been highlighted more than other agents. Kobayashi et al. ${ }^{13}$ indicated that the thiopental had a greater suppressive effect on neuronal injury during identical duration of ischemic depolarization than halothane and propofol does, which can be due to its lower influence on hemodynamic alteration. Moreover, it seems that the effects of both anesthetic agents are dose-dependent and should be regulated on the basis of patient's age and clinical condition. It was previously attributed the mechanism for the $50-67 \%$ decrease in the required dose of thiopental for induction of anesthesia in aged human patients to a decrease in the initial distribution volume for thiopenta ${ }^{14}$. It has been also concluded that the required dose of thiopental should be regulated by the evaluation of patient's blood gas situation so that the increase of thiopentone binding in human serum was more pronounced at $\mathrm{pH} 6$ to 6.8 than at $\mathrm{pH} 7.4^{15}$. However, all patients with underlying disorders could cause blood gas alteration were excluded from the study.

In the present study, it was also found that the arterial oxygen saturation was similar between the two groups in all points of time and did not change within the time points of 1 to 40 minutes in both groups. However, previous findings indicated that the halothane and thiopental used at clinically relevant concentrations modulate the pulmonary SP-C mRNA content in animal models. It has been also confirmed that the volatile anesthetics can reduce surfactant phospholipid biosynthesis by rat alveolar type II cells ${ }^{16}$. However, respiratory effects of both agents should be more investigated in further human studies.

There are some potential limitations in interpreting these data. Our randomized clinical study was an open-label investigation, necessitated by the various modes of drug administration and the differing physical appearances of the anesthetic and analgesic drugs. However, the personnel caring for study patients in the postoperative period were unaware of the anesthetic and analgesic drugs given intra-operatively and thus remained unbiased.

\section{Conclusions}

Continuous infusion of thiopental can be applied effectively and safely for maintenance of anesthesia. In comparison with halothane, it is associated with lower changes of intraoperative hemodynamics and faster anesthesia recovery.

\section{References}

1. Goelz MF, Hahn AW, Kelley ST. Effects of halothane and isoflurane on mean arterial blood pressure, heart rate, and respiratory rate in adult Pekin ducks. Am J Vet Res. 1990;51(3):458-60.

2. Dedhia KN, Kudalkar A. Comparison of sevoflurane and halothane for induction of anesthesia and laryngeal mask airway insertion in pediatric patients. Indian J Anesth. 2004;48(6):465-8.

3. Kyei-Mensah K. Heart rate changes in halothane anaesthesia: effect of varying doses of atropine and neostigmine. Br J Anaesth. 1973;45(5):507-10.

4. Murray DJ, Forbes RB, Mahoney LT. Comparative hemodynamic depression of halothane versus isoflurane in neonates and infants: an echocardiographic study. Anesth Analg. 1992;74(3):329-37.

5. Saito S, Kadoi Y, Nara T, Sudo M, Obata H, Morita T, Goto F. The comparative effects of propofol versus thiopental on middle cerebral artery blood flow velocity during electroconvulsive therapy. Anesth Analg. 2000;91(6):1531-6.

6. Dottori O, Löf BA, Ygge H. Heart rate and arterial blood pressure during different forms of induction of anaesthesia in patients with mitral stenosis and constrictive pericarditis. Br J Anaesth. 1970;42(10):849-58.

7. Singh J, Mirakhur KK, Sobti VK, Kohli RN. Hemodynamics, blood gas and metabolic alterations during thiopental anaesthesia in buffaloes. Zentralbl Veterinarmed A. 1980;27(9-10):730-9.

8. Fitzmaurice GM, Laird NM, Ware JH. Modeling the mean: analyzing response profiles. Applied longitudinal analysis. New Jersey: John Wiley and Sons; 2004. p.103-18.

9. Büch U, Altmayer P, Isenberg JC, Büch HP. Increase of thiopental concentration in tissues of the rat due to an anesthesia with halothane. Arzneimittelforschung. 1991;41(4):363-6.

10. Lees P, Tavernor WD. Influence of halothane and catecholamines on heart rate and rhythm in the horse. Br J Pharmacol. 1970;39(1):14959.

11. Avram MJ, Krejcie TC, Niemann CU, Klein C, Gentry WB, Shanks CA, Henthorn TK. The effect of halothane on the recirculatory pharmacokinetics of physiologic markers. Anesthesiology. 1997;87(6):1381-93.

12. Tsuchiya S, Kanaya N, Hirata N, Kurosawa S, Kamada N, Edanaga M, Nakayama M, Omote K, Namiki A. Effects of thiopental on bispectral index and heart rate variability. Eur J Anaesthesiol. 2006;23(6):454-9.

13. Kobayashi M, Takeda Y, Taninishi H, Takata K, Aoe H, Morita K. Quantitative evaluation of the neuroprotective effects of thiopental sodium, propofol, and halothane on brain ischemia in the gerbil: 
Anesthetic recovery and hemodynamic effects of continuous thiopental infusion versus halothane for maintenance anesthesia in patients undergoing ocular surgery

effects of the anesthetics on ischemic depolarization and extracellular glutamate concentration. J Neurosurg Anesthesiol. 2007;19(3):1718.

14. Stanski DR, Maitre PO. Population pharmacokinetics and pharmacodynamics of thiopental: the effect of age revisited. Anesthesiology. 1990;72(3):412-22.

15. Christensen JH. Individual variation in response to thiopentone. Dan Med Bull. 1989;36(3):281-98.

16. Paugam-Burtz C, Molliex S, Lardeux B, Rolland C, Aubier M, Desmonts JM, Crestani B. Differential effects of halothane and thiopental on surfactant protein $\mathrm{C}$ messenger RNA in vivo and in vitro in rats. Anesthesiology. 2000;93(3):805-10.
17. Mora CT, Dudek C, Torjman MC, White PF. The effects of anesthetic technique on the hemodynamic response and recovery profile in coronary revascularization patients. Anesth Analg. 1995;81(5):90010.

18. Nussmeier NA, Arlund C, Slogoff S. Neuropsychiatric complications after cardiopulmonary bypass: cerebral protection by a barbiturate. Anesthesiology. 1986;64(2):165-70.

19. Oxorn D, Orser B, Ferris LE, Harrington E. Propofol and thiopental anesthesia: a comparison of the incidence of dreams and perioperative mood alterations. Anesth Analg. 1994;79(3):553-7.

\section{Correspondence:}

\section{Ali Abbasi}

Department of Epidemiology

University Medical Center Groningen,

Hanzeplein 1, P.O. Box 30.001, 9700 RB

Groningen, Netherlands

Phone/Fax: 0031503618068

aliiabbasi@yahoo.com; a.abbasi@epi.umcg.nl
Conflict of interest: none Financial source: Tehran University of Medical Sciences

Received: November 10, 2010

Review: January 18, 2011

Accepted: February 22, 2011 